\title{
When does human life begin?: an evolutionary perspective
}

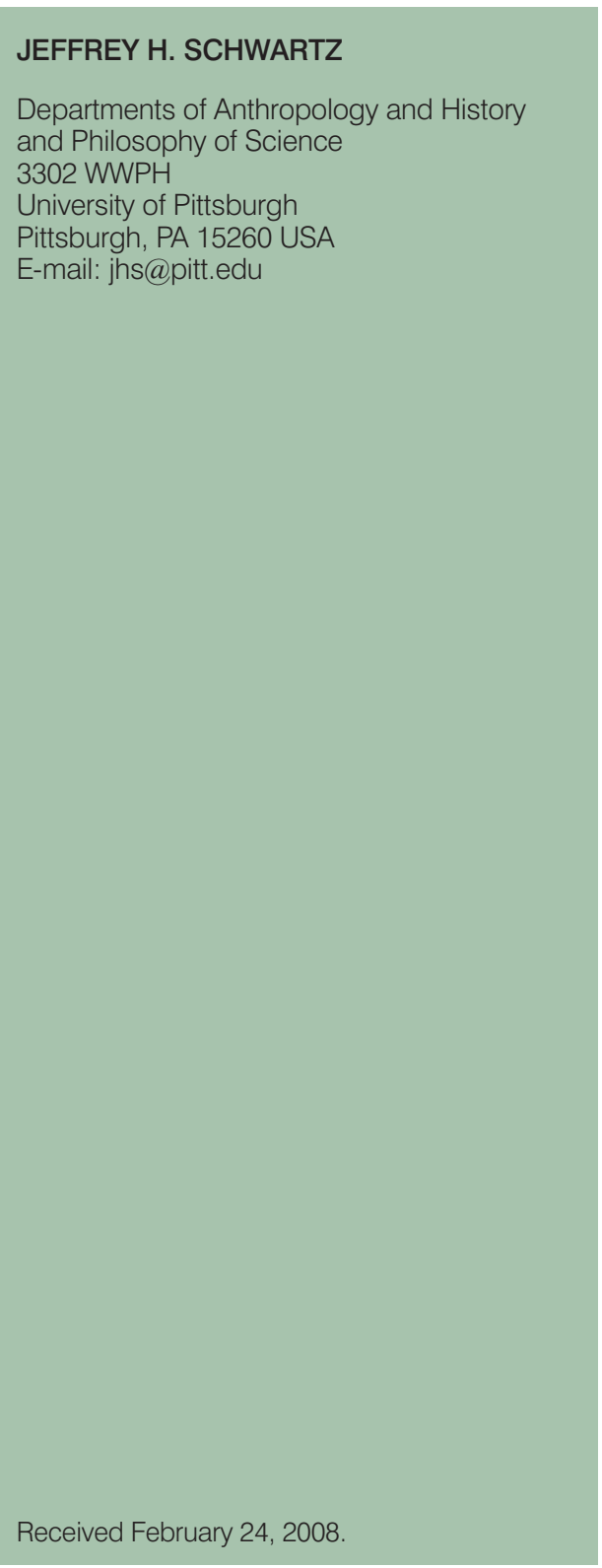

\section{Abstract}

The question - "when does human life begin?" - is without doubt an important one, and the answer to it has different yet equally profound consequences in diverse fields such as medicine, theology, ethics, and anthropology. But before one can begin to tackle the topic and its ramifications, one must first be certain that that one is not conflating a conception about "the beginning of human life " with the biology relating to "the beginning of life «. Here I shall discuss these issues from the perspectives of the history and philosophy of science and evolutionary biology with the hope that this might shed light on the multifaceted and hierarchical nature of this typically highly charged subject.

\section{INTRODUCTION}

There is arguably no question more likely to provoke heated debate 1 among life, medical, and social scientists, ethicists, philosophers, and theologians than »When does human life begin? "Depending on the answer and the use to which it is put, the consequences can be profound and indeed even grave. If the answer is that human life begins »at fertilization, « one may be bound to a moral and ethical contract that begins with a single, non-descript, pre-implantation cell and concludes after dozens of cell divisions with an organism that has form, can move, and is filled with sensory awareness. But another element that must be considered is whether when probing the question »When does human life begin? « the inquiry is actually not focused on this specific question, but rather on the question »When does life begin? «I raise this point because it seems, to me at least, that the argument can be made that there is a fundamental difference between an inquiry into the beginning of life and an inquiry into the emergence of being or becoming human. Although any attempt to add scientific neutrality and objectivity to the probing of this question will no doubt fall on some deaf ears, it might be useful and informative to tackle it from a less frequently traveled intellectual course: that of evolutionary biology and from the perspective of the history and philosophy of science.

\section{A BRIEF HISTORICAL REVIEW}

\section{Pre-evolutionary Concepts of Development}

In the intellectual world prior to the recognition in the mid- $19^{\text {th }}$ century that life can and does evolve, taxonomists and systematists em- 
braced the biblically dictated belief that the progenitors of all species - plant as well as animal - had been created individually and placed on earth by a divine being. Thus for these »scholars «, the primary criterion for identifying species was whether individuals could mate and produce not only viable, but reproductively sound offspring (1). The rationale behind the "sterility test « approach to defining species lay in the belief that since a divine being had created separate forms of life, their interbreeding would constitute an unnatural act. Consequently, if two individuals produced offspring that were themselves capable of reproducing, this meant that its parents had to belong to the species lineage that descended from the originally created stock.

With the advent of the microscope and the discovery first of sperm and then of ova in mammals in the late $17^{\text {th }}$ and early $18^{\text {th }}$ centuries, the focus shifted from the sex organs themselves as the source of a species' future generations to the sex cells (1). Yet, because the pursuits of science and the interpretation of the life histories of individuals were dominated by a strict reading of the Book of Genesis, the widespread belief among European scholars was that all future generations of a species, humans included, were contained in the reproductive organs or cells of either the males or females and received intact from the first-created male or female of that species. If one was a spermist, the ovum was ancillary to the process of heredity; if one was an ovist, one embraced the converse. Nevertheless, the belief in the existence of tiny but fully preformed individuals - homunculi - lying one within another like a nested set of Russian dolls dominated the study of embryology and comparative anatomy $(2,3)$. In spite of Caspar Wolff's 1759 demonstration using chicken eggs that the vertebrate embryo emerges from initially undifferentiated biological matter and that during development its embryonic and then juvenile features are transformed into those of the adult, the preformationist dogma persisted, in large part because of the widespread clout of the Swiss-born professor of medicine at the University of Göttingen, Albrecht von Haller. Although not embracing the scenario of preformationism in its entirety, especially the element of miniature individuals being contained one within another, Haller was convinced that the chick was present but invisible in the unfertilized egg; upon fertilization, the heart of the bird, within which lay the invisible generations of chicks to come, began to beat and eventually the animal became visible (ibid.). The reason this »event « was not observable in mammals was that, in contrast to a bird's egg, mammalian ova are much too tiny to study microscopically.

Fortunately, albeit somewhat belatedly, the embryologist Johann Meckel's German translation of Wolff's Latin publication of his theory of epigenesis - as Wolff termed the process through which a developing organism becomes increasingly complex as it differentiates into specialized parts - made Wolff's observations and interpretations accessible to other embryologists. Importantly, and in anticipation of the work of the German em- bryologist Karl Ernst von Baer (4), Wolff realized that, when comparing the developmental stages of organisms, one was not comparing analogues of adult individuals, which was what these stages were more widely interpreted as representing. To the contrary, when comparing the ontogenies of different organisms, the only aspects of their development organisms have in common are the not-yet or not-fully differentiated embryonic or fetal stages, from which they subsequently diverge as they mature and acquire the distinctive features of the adults of their specific species. Consequently, for example, the supposed gill-slit stage in vertebrate development does not represent an adult fish, but merely a transitory phase through which any vertebrate passes as it becomes progressively transformed into its adult morphologies.

In spite of Meckel's popularization of Wolff's work, its implications had little impact on the disciplines of comparative anatomy and embryology until von Baer (e.g. 1828) recast them into four statements that became known as von Baer's laws. These were: 1) during the development of an organism, general anatomical features appear before the more specialized ones; 2) specialized features develop from generalized characters; 3) an organism acquires the characteristics of its group and of its species during its development, as a result of which it becomes increasingly different from other organisms; and most importantly, 4) the early ontogenetic stages of an organism are not equivalent to the adult stages of organisms lower in the hierarchical scale of creation, but, rather, are representative of the early ontogenetic stages of less complex organisms farther down the ladder of creation (5).

The contrast between preformationist and epigenetic ideas redounds on the question When does human life begin? «For, if each individual of each future generation of a species is not contained in miniature in either the male or female of that species, but instead »evolves« or, as the word »evolution « was originally defined, »unfolds « as the individual passes through a developmental path that proceeds from the generalized and undifferentiated to the differentiated and specific, then there must be a point at which the embryo or fetus transitions from not being to being human. But then the question becomes »What distinguishes a human from other animals? « and this question is one that had plagued comparative anatomists, such as Edward Tyson, for more than a century.

\section{Edward Tyson and the Anatomy of the Pygmie}

Although a comparative anatomist of some note, having been acknowledged as such by von Haller and other contemporaneous luminaries and having published among other seminal works the first detailed description of a dolphin (6), Tyson is arguably most widely known for his 1699 treatise on the comparative anatomy of what he thought was an ape or ape-like animal, which he believed was the animal classical authors were referring to when they discussed creatures such as »pygmies « and »satyrs« (7). In the latter work, the first edition of which 
was published under the title Orang-outang, sive, Homo sylvestris: or, The anatomy of a pygmie compared with that of a monkey, an ape, and a man, Tyson (8) actually described the anatomy of a juvenile chimpanzee, which is an error that somewhat compromises his comparisons with the adults whose anatomies were described in the contemporaneous sources he had at his disposal (ibid.). Further, one must be cognizant of the fact that during the $17^{\text {th }}, 18^{\text {th }}$, and even well into the $19^{\text {th }}$ century, the term »ape« was used to refer both to monkeys (»tailed apes«) and to proper apes (the »man-like« or »tailless apes«, i.e. gibbons, chimpanzees, gorillas, and orangutans) (9), with the result that various Old World monkeys, such as stump-tailed macaques, were incorrectly grouped with proper apes (10). Nevertheless, Tyson's work stands as the first rigorous and detailed study of the comparative anatomy of representatives of a group of primates that would become recognized and classified as Anthropoidea (11).

The major consequence of Tyson's comparisons that relates to the central question of the workshop represented in this compendium is the discovery that his specimen of "pygmie « was unexpectedly (and obviously shockingly) similar and even often virtually identical to humans not only in musculoskeletal anatomy, but also in soft-tissue anatomy, including aspects of the brain. When differing noticeably from humans, this "pygmie« was clearly similar to the »apes « used in the comparison. In the dedication of his treatise to Lord Evesham, Tyson (p. 2) wrote:

What I shall most of all aim at in the following Discourse, will be to give as particular an Account as I can, of the formation and structure of all the Parts of this wonderful Animal and to make a Comparative Survey of Men, with the same Parts in a Humane Body, as likewise in the Ape and Monkey-kind. For tho' I own it to be of the Ape kind, yet, as we shall observe, in the Organization of abundance of its Parts, it more approached to the Structure of the same in Men: But where it differs from a Man, there it resembles plainly the Common Ape, more than any other Animal...But at the same time I take him to be wholly a Brute, tho' in the formation of the Body, and in the Sensitive or Brutal Soul, it may be, more resembling a Man, than any other Animal; so that in this Chain of the Creation, as an intermediate Link between an Ape and a Man, I would place our Pygmie.

Clearly, if a divine being had created all creatures on earth individually according to the story of Genesis, there should be greater difference between this "pygmie« and especially a human, who was not only the last life-form to be created, but the only one to be created in the image of this divine being. Such a vast difference not being the case, however, the question that had to be confronted was what, precisely, does distinguish a human from other animals? And it is here that Tyson seeks answers in the intangible, the non-anatomical: a soul.
Where, then, in a human's anatomy might one seek the seat of the soul? For Tyson (p. 54) the obvious answer was the brain:

That the Brain is reputed the more immediate Seat of the Soul it self, one would be apt to think, that since there is so great a disparity between the Soul of a Man, and a Brute, the Organ likewise in which 'tis placed should be very different too.

Yet, to his complete surprise, the resemblance between the brain of his "pygmie" and that of a human was "so great...that nothing could be more (p. 54) - which led him to conclude (p. 54-5):

Since there in all respects the Brain of our Pygmie does so exactly resemble a Man's...there is no reason to think, that Agents do perform such and such Actions, because they are found with Organs proper thereunto: for then our Pygmie might be really a Man. The Organs in Animal Bodies are only a regular Compages of Pipes and Vessels, for the Fluids to pass through, and are passive. What actuates them, are the Humours and Fluids: and Animal Life consists in their due and regular course in this Organical Body. But those Nobler Faculties in the Mind of Man, must certainly have a higher Principle; and Matter organized could never produce them; for why else, where the Organ is the same, should not the Actions be the same too? And if all depended on the Organ, not only our Pygmie, but other Brutes likewise, would be too near akin to us...[I]n truth Man is part a Brute, part an Angel; and is that Link in the Creation, that joyns them both together.

In the end, not the least because Tyson was a creationist whose science was dominated by the strictures of the Great Chain of Being, the difference between »man « and the most similar of the »brutes « was sought in the supernatural and metaphysical: both realms of inquiry that were grounded not in scientific practice, but pursued through religion-based inspiration and revelation.

\section{Post-evolutionary Concepts of Development}

To return to the primary focus of this contribution evolutionary biology, especially evolutionary developmental biology, and the question »When does human life begin? « - the course of history in the decades that followed von Baer's embryological publications led to the recognition that life does indeed evolve and thus, the initial work of a divine being in creating life notwithstanding, the founding individual's of the myriad species of plant and animal were not specially created, but instead resulted from either some specific kind, or a combination of natural processes $(12,13)$. Since Darwin (12) did not broach the subject of human evolution in any edition of On the Origin of Species (14), and did not make public The Descent of Man until 1871, in which he did attempt to do so, the initial intellectual undertaking fell to Thomas Henry Huxley. 
In 1863 Huxley published the results of this endeavor in one of three essays compiled in the small volume Man's Place of Nature titled »On the relation of Man to the Lower Animals. «As Huxley (14) related in the preface to the second edition of Man's Place in Nature, he started down this path of inquiry in 1854 , when he was required to teach »the principles of biological science with especial reference to paleontology « and through this experience he was forced to confront his »lamentable ignorance in respect of many parts of the vast field of knowledge« (p. viii). As a result of trying to correct this situation, Huxley began to realize that »the position of the human species in zoological classification « was a serious problem. As he wrote (clarification added):

Even among those who considered man from the point of view, not of vulgar prejudice, but of science, opinions lay poles asunder. Linnaeus had taken one view, [the French paleontologist and creationist] Cuvier another; and, among my senior contemporaries, men like [the doyenne of English geologist and creationist-turned-evolutionist] Lyell, regarded by many as revolutionaries of the deepest dye, were strongly opposed to anything which tended to break down the barrier between man and the rest of the animal world.

Indeed, Huxley continued, the issue of »Man's place in nature " was such a volatile topic that »those who touched it were almost certain to burn their fingers severely.«

Huxley was further inspired to pursue this issue in 1857, when he heard Sir Richard Owen, a dominant figure among English anatomists, deliver a paper in which the latter scholar pronounced that because humans were supposed to possess the most highly developed brains, they should be classified well apart from the rest of animals and placed in their own group, Archencephala. Further fueled by Darwin's (12) reluctance to tackle the question of human evolution in the Origin, Huxley decided to explore this topic himself. As he stated in 1896: »Inasmuch as Development and Vertebrate Anatomy were not among Mr. Darwin's many specialties, it appeared to me that I should not be intruding on the ground he had made his own, if I discussed this part of the general question ... In fact, I thought I might probably serve the cause of evolution by doing so« (p. viii). In 1862, Huxley's efforts were bolstered by Sir William Henry Flower's demonstration that the supposedly unique features of the human brain that Owen had cited as the basis for separating humans from other primates were also seen in the brains of »apes«. Huxley published the first edition of Man's Place in Nature the following year.

Were this a discussion of virtually any other topic, such a long preamble to a review of Huxley's essay might have been seen as excessive. But I believe this historical overview helps situate the intellectual - indeed, the philosophical as well as theoretical - breach between Huxley and Darwin that is evident not only in Huxley's (15) rejection of Darwin's (12) argument for the origin of spe- cies gradually and by means of natural selection, but also in the contradictory developmental perspectives that informed Huxley and Darwin's disparate models of evolutionary change (16). Specifically, the latter disagreement mirrored precisely the diametrically opposed interpretations offered by earlier embryologists of the significance of organisms sharing similar ontogenetic stages or phases.

Although it is common knowledge that the embryologist, comparative anatomist, and paleontologist Ernst $(2,17)$ Haeckel embraced Darwin's theory of evolution by means of natural selection in the face of opposition from England's most prominent comparative anatomists and saltational evolutionists, Huxley (15) and especially Mivart (16), one if not the primary reason for the intellectual bond between the former two evolutionists lies, I believe, in how they interpreted an organism's development . Namely, while it is well known that Haeckel saw in an organism's ontogenetic stages an evolutionary history represented by a sequence of adult ancestors - which formed the basis of his biogenetic law (»ontogeny recapitulates phylogeny«) - it is at first glance less obvious that Darwin did so as well. Yet, if one considers the object of Darwin's theory of evolution by means of natural selection, and the fact that Darwin was a staunch advocate of use-disuse explanations as the basis for organismal change (as in the phrase, »an organism's desires can engender change ) (1), and that the very real impact of use-disuse behavior or activity on an organism's being was one of the pillars of the theory of inheritance he called »pangenesis« (18), it is obvious that Darwin's focus was the adult, or at the very youngest the postnatal individual (16).

This conclusion becomes obvious when one recognizes that natural selection cannot act on, and a history of life experience cannot indelibly impose and subsequently imprint itself upon an individual that is not yet available to it. In the case of use-disuse arguments and Darwin's theory of pangenesis, organism-changing life-history events are passed on to offspring through »gemmules « (some kind of substances or particles, but not in the sense of Mendelian particulate inheritance, that accumulate in an individual's sex organs) that »record « the alterations of organs or body parts of any particular individual as well as the alterations of individuals of preceding, ancestral generations (1). If one contemplates Darwin's staunch and life-long opposition to saltational change and his unfaltering dedication to gradual change, it becomes obvious why he was not interested in the prenatal individual: All the »information « relevant to his model of evolution was acquired during an individual's postnatal lifetime.

Contrast this predisposition with that of saltationism, which was embraced by Huxley and most ardently championed by St. George Mivart (1). From a saltationist's perspective, potential morphological novelty, and thus potential evolutionary change, results from perturbations that alter an organism's course of prenatal development, its ontogeny. Novel features do not emerge through a process of gradual modification of adults, in which one 
or another slight variation was weeded out by selection or the vicissitudes of life leave an indelible and heritable imprint through use-disuse. To the contrary, as saltationists interpreted the situation, a novel feature, or a change in an existing one, had to emerge through an altered, but biologically integrated and successfully coordinated course of development, especially if the resultant novel attribute (such as an eye, a lung, a limb, or a reproductive organ) were to be functional. This is not to say that any alteration of an organism's ontogeny would produce a viable individual with a novel feature. Rather, only if all aspects of an organism's development were in synchrony throughout the ontogenetic continuum of the alteration until final form was achieved would the bearer of the resultant novelty survive and pass on this »feature or »trait« to its offspring.

Consequently, given Huxley's intellectual predisposition toward the centrality of large-scale developmental changes in producing evolutionarily significant changes, it should come as no surprise to find in his argument for "Man's place in Nature « in the essay »The Relation of Man to the Lower Animals« that he embraced von Baer's (and by historical precedent also Wolff's) emphasis on prenatal organismal differentiation. More specifically, and in contrast to Haeckel and also Darwin's focus on the recapitulation in the ontogeny of an individual of the life-histories of its postnatal ancestors, it makes sense that Huxley also embraced von Baer's interpretation of similar ontogenetic phases among vertebrate embryos as evidence of common fetal phases of development rather than as evidence of a historical sequence of shared adult - ancestors.

In »The Relation of Man to the Lower Animals" Huxley began by discussing fundamental aspects of the ontogeny of the dog, from fertilized egg to the eventual differentiation of the fetus and its placental link to its mother's womb. Against this developmental yardstick, Huxley then compared the ontogenies of lizard, snake, frog, fish, bird, cat, opossum, and monkey. He wrote: »the embryos of a Snake and of a Lizard remain like one another longer than do those of a Snake and of a Bird; and the embryo of a Dog and of a Cat remain like one another for a far longer period than do those of a Dog and a Bird; or of a Dog and an Opossum; or even those of a Dog and a Monkey« (p. 98). Clearly, organisms that share common embryonic and fetal phases over a longer period of their development will as adults appear as belonging to the same group of organism. This Huxley found was the case even if the shapes of the adult animals were not necessarily look exactly mirror images of each other, as in the case of a limbless snake and a typical four-legged reptile.

Following von Baer's rules, Huxley pointed out that »the more closely any animals resemble one another in adult structure, the longer and the more intimately do their embryos resemble one another« (p. 98). Thus, he argued, from an evolutionary perspective it should not be surprising to discover that the ontogenetic paths of a dog (a carnivore) and a cat (another carnivore) remain more similar to each other over a longer period of time than do the ontogenetic paths of a dog and bird, or of a dog and monkey. Having presented this relatively innocuous and noninflammatory conclusion, Huxley could to the question of »man's place in nature«:

The study of development affords a clear test of closeness of structural affinity, and one turns with impatience to inquire what results are yielded by the study of the development of Man. Is he something apart? Does he originate in a totally different way from Dog, Bird, Frog, and Fish, thus justifying those who assert him to have no place in nature and no real affinity with the lower world of animal life? (p. 101)

Not unexpectedly from the perspective of the $21^{\text {st }}$ century, the answer Huxley meant to provoke in his readers with this question was, of course, »no. « If dogs, birds, frogs, and fish are united by a common ontogeny, then, if this were also shown to be true of humans, they, too, must be included with »lower « animals. And if length and detail of shared ontogenetic paths does reflect the acquisition of similar anatomical attributes then, if this were also shown to be true of humans and only some non-human animals, then the only logical conclusion was not only that humans are firmly entrenched biologically and evolutionarily in the animal world, but also and importantly that they are most intimately associated with only a few members of that animal world, the apes. And indeed, as Huxley more than adequately demonstrated in this concise essay, a comparative study of human prenatal development, from fertilized egg through embryonic differentiation and fetal growth, could be interpreted in only one way: namely that »without a doubt, in these respects, he [»Man«] is far nearer the Apes, than the Apes are to the Dog $«$ (p. 102) (comment added). (N.B.one must here be aware that Huxley did not inform his audience of the specific »apes« to which he referred).

Having established this first foothold in what had previously been intellectual terra incognita, Huxley then proceeded to provide evidence that would lead to the same conclusion through intertaxic comparisons of other anatomies. Still in the prenatal mode of argumentation, Huxley turned next to the mammalian placenta. Because not all the vertebrates in his previous comparisons were mammals, Huxley perforce limited his comparison of placental development to humans, »apes« and the dog. And, not surprisingly, it was also in the configuration of the placenta that Huxley found convincing similarity between apes and humans, a similarity that did not exist between humans and the other mammal of comparison, the dog. Granted, there were some general similarities between humans and dogs in the general growth of the placenta - especially in the early phases of »yelk « (yolk) sac and allantois development - that struck Huxley as »sufficient to place beyond all doubt the structural unity of man with the rest of the animal world.« But the more specific similarities between humans and apes, such as »a spheroidal yelk-sac and a discoidal, sometimes partially lobed, placenta, «which would appear later in their shar- 
ed ontogenies, were irrefutable demonstrations of the unity of humans »more particularly and closely with the apes.«

According to Huxley (14), without his groundbreaking study and its near-heretical conclusion, Darwin (19) would not have had the confidence to engage in a discussion of human evolution in The Descent of Man. Whether or not this contention is true - which, given Darwin's reliance not on his own but on the descriptive and comparative work of vertebrate anatomists for all the information contained in Descent, I suspect it actually is - it is the case the Darwin does extensively cite Huxley's essay in this tome. And this in and of itself is of historical interest because, as I argued above, Huxley's embrace of von Baer's interpretation of the significance of favorable ontogenetic comparisons between taxa, which was consistent with his saltational ideas, was likely a major reason he could never accept Darwin's focus on the postnatal individual. But a question that then emerges is whether or not von Baer's via Huxley's interpretation of shared ontogenetic »stages« or »phases« as reflecting not common adult ancestors, but rather stages or phases of development in which no individual species can be specified or recognized, has stood the test of time.

\section{EVOLUTIONARY DEVELOPMENTAL BIOLOGY NOW}

Among the questions addressed during this workshop was the following: »If the beginning of human life can be specified embryologically, does this moment of becoming human occur at fertilization, with the emergence of the multicellular morula, or at some later time during embryogenesis? " The question these questions beg is whether there is any detectable difference between humans and other sexually reproductive metazoans at any of these defined moments. If there is, then from an evolutionary and developmental point of view, there should be processes - mechanical, physical, molecular - that early on distinguish human embryogenesis and later development from all other metazoans. More broadly, if the latter is true, then there should be mechanical, physical, and molecular processes that distinguish each metazoan species from every other metazoan species. This, however, would not seem to be the case.

Descriptively, from blastocyst orientation and implantation through fetal membrane and placental development, the details of human embryogenesis are not only identical to those of »apes, « they are essentially identical to those of all anthropoid primates (i.e. large- and small-bodied hominoids and Old and New World monkeys) (20). In between, from the onset of cell division through gastrulation, human embryogenesis is indistinguishable, macroscopically at least, from that of other vertebrates/mammals (21).

If humans are part of nature, and not specially created, then we would expect that the same properties and/or processes that through gastrulation govern the three-dimensional packing and spatial relationship of cells in macroscopically similar embryos (22) also obtain to our species. Consequently, there is nothing particularly human about Hox gene expression that establishes in the anterior-posterior axis common to all chordates or the subsequent expression of the transcription factorproducing gene Brachyury in the development of the chordate notochord (23). Indeed, the fact that the four Hox gene clusters of tetrapods are the result of gene duplication of the Hox genes present in invertebrates (as the eight Hox gene clusters of teleost fish are the result of gene duplication of the four Hox gene clusters retained in tetrapods), and Brachyury gene expression occurs in different regions of the larvae of vastly different metazoans (ibid.), and it is well known that cells of the same type can yield a diversity of physiological traits from a the same, single set of genes (23) one can hardly think of any of these constituents of tightly constrained signal transduction pathways as being taxon specific. Further, as Gehring (25) pointed out, there is nothing essentially organ-specific about any given transcription factor since "there is no functional necessity to use a particular transcription factor like Pax 6 for a particular function, e.g. eye morphogenesis, since a transcription factor can regulate any gene, if this gene is endowed with the appropriate regulatory elements in its enhancer or promoter."

Beyond the genetic, however, are also the physical (26) and epigenetic $(27,28)$ influences on the emergence of three-dimensional organismal form. Consequently, »free diffusion, chemically excitable behavior, oscillation and mutistability of chemical state, reaction diffusion coupling and mechanochemical responsivity« (26), as well as the constraints on cell packing of symmetrical versus asymmetrical cell division (27) and the subsequent consequences of evagination versus invagination (29), coupled with epigenetic factors (e.g. the methylation or demethylation of DNA) on initially pluripotent (30) cells can lead first to various similar basic body plans from which increasingly more specific shapes may emerge, but without altering the basic developmental »tool-kit « (26). In short, the essential »steps « leading to the formation any tetrapod embryo, whether human or not, rely not only on the same processes, but also on the same molecular elements and physical constraints.

\section{CONCLUSION}

As the forgoing has hopefully illustrated, the saltationists - led by Huxley and Mivart - were clearly attuned to the potential of alteration of development to produce novelty. By embracing von Baer's focus on those aspect of ontogeny that are common to all vertebrates at least, Huxley and Mivart anticipated insights now emerging from developmental biology that Darwin could never have imagined because of his emphasis on the postnatal individual.

More specifically relevant to the theme of the workshop represented in this issue is the realization that, from a biological perspective, the pluripotency of cells, the representation in the cells of all metazoans of the same basic 
tool-kit of developmental molecules, and the effects on shape of the same physical properties, makes clear the gulf between the questions »when does life begin? « and "when does human life begin? "The former is a scientific question that has a simple scientific question. Since gametes - sex cells - are living cells, they constitute the basic units of life. Their union only adds a different level of complexity, as do subsequent cell divisions, cell-cell interactions, and cell-cell spatial relationships. From both biological and evolutionary perspectives, there is nothing more »special« about the growth and development of a human than a fish or a frog. As such, unless we insist that there is some other »quality « or »essence« from the very beginning, or at least early on in development, that sets humans apart from the rest of the organic world, we should be compelled to expand our concern for protecting the unborn human to all living creatures.

Acknowledgements: I thank Dr. Asim Kurjak for inviting me to contribute to this volume.

\section{REFERENCES}

1. SCHWARTZ J H 1999 Sudden Origins: Fossils, Genes, and the Emergence of Species. John Wiley \& Sons, New York.

2. HAECKEL E 1876 The Evolution of Man: a Popular Exposition of the Principal Points of Human Ontogeny and Phylogeny, 3rd edn. H.L. Fowle, New York.

3. MASON S F 1962 A History of the Sciences. Collier Books, New York.

4. von BAER K E 1828 Über Entwicklungsgeschicte der Thiere: Beobachtung und Reflexion. Bornträger, Königsberg.

5. GOULD S J 1977 Ontogeny and Phylogeny. The Belknap Press of Harvard University Press, Cambridge, MA.

6. RUSSELL K F 1967 Review of Edward Tyson's Orang-Outang (a facsimile). Medical History 11: 417-423

7. MONTAGU A M F 1943 Edward Tyson, M.D., F.R.S., 1650-1708, and the rise of human and comparative anatomy in England; a study in the history of science. American Philosophical Society, Philadelphia.

8. TYSON E 1699 Orang-outang, sive, Homo sylvestris: or, The anatomy of a pygmie compared with that of a monkey, an ape, and a man. Thomas Bennet, London.

9. SCHWARTZ J H 2005b The Red Ape: Orangutans and Human Origins. Westview Press, Boulder, CO.
10. Buffon G L L, comte de 1765 Histoire naturelle, gènèrale et particulière. Limprimerie du Roi, Paris.

11. FLOWER W H 1883 On the arrangement of the orders and families of existing Mammalia. Proceedings of the Zoological Society of London: $178-186$

12. DARWIN C 1859 On The Origin of Species by Means of Natural Selection, or the Preservation of Favored Races in the Struggle for Life. John Murray, London.

13. MIVART S G 1871 On the Genesis of Species. John Murray, London.

14. HUXLEY T H 1896 Evidence as to Man's Place in Nature, 2nd edn D. Appleton, New York.

15. HUXLEY T H 1860 Review of »The Origin of Species« In: The Westminster Review, vol 17 (n.s.), p 22-79

16. SCHWARTZ J H 2005a Darwinism versus Evo-Devo: a late $19^{\text {th }} \mathrm{c}$. debate. In: Mueller-Wille S, Reinberger H-J (eds) A Cultural History of Heredity III: $19^{\text {th }}$ and early $20^{\text {th }}$ Centuries, vol Preprint 294. Max Planck Institute for the History of Science, Berlin, p 67-84

17. HAECKEL E 1866 Generelle Morphologie der Organismen. Georg Reimer, Berlin.

18. DARWIN C 1868 The Variation of Animals and Plants under Domestication. John Murray, London.

19. DARWIN C 1871 The Descent of Man and Selection in Relation to Sex. John Murray, London.

20. LUCKETT W P 1974 Comparative development and evolution of the placenta in primates. Contributions to Primatology 3: 142-234

21. GILBERT S 2006 Developmental Biology. Sinauer, Sunderland, MA.

22. SCHIFMANN Y 2006 Symmetry breaking and convergent extension in eaerly chordate development. Biophysics and Molecular Biology 92: 209-231

23. SWALLA B J 2006 Building divergent body plans with similar genetic pathways. Heredity 97: 235-243

24. NEWMAN J R S, WEISSMAN J S 2006 Many things from one. $\mathrm{Na}$ ture 444: 561-562

25. GEHRING W J 2002 The genetic control of eye development and its implications for the evolution of the various eye-types. International Journal of Developmental Biology 46: 65-73

26. NEWMAN S A, FORGACS G, MÜLLER G 2006 Before programs: the physical origination of multicellular forms. International Journal of Developmental Biology 50: 289-299

27. LØVTRUP S 1974 Epigenetics: a treatise on theoretical biology John Wiley \& Sons, New York.

28. REIK W 2007 Stability and flexibility of epigenetic gene regulation in mammalian development. Nature 447: 425-432

29. OSTER G, ALBERCH P 1982 Evolution and bifurcation of developmental programs. Evolution 36: 444-459

30. STEMMERIK L, ROUSE J E, SPIRO B 2000 S-isotope studies of shallow water, laminated gypsum and associated evaporites, Upper Permian, east Greenland. Sedimentary Geology 58: 37 